\title{
Statin use is not associated with reduced risk of skin cancer: a meta-analysis
}

\author{
$\mathrm{XLi}^{1}, \mathrm{X} \mathrm{B} \mathrm{Wu}{ }^{1}$ and $\mathrm{Q} \mathrm{Chen}^{\star}, 1$ \\ ${ }^{1}$ Department of Epidemiology, School of Public Health and Tropical Medicine, Southern Medical University, Guangzhou, China
}

Background: There is contradictory evidence about the association between statin and skin cancer.

Methods: Literature search in PubMed and Web of Science was undertaken up to June 2013. Pooled relative risk (RR) estimates and $95 \%$ confidence intervals $(\mathrm{Cls})$ were calculated.

Result: A total of 21 articles with 29 studies were identified. No association was found between statin and skin cancer among neither melanoma (RR, 0.94; 95\% Cl, 0.85-1.04) nor non-melanoma skin cancer (RR, 1.03; 95\% Cl, 0.90-1.19).

Conclusion: Our meta-analysis does not support a potential role of statin use in the prevention of skin cancer.

Skin cancer is one of the most common cancers, which is divided into two major groups, melanoma and non-melanoma skin cancers (NMSCs). Melanoma is the major cause of death from skin cancer (Society, 2013) and considered as one of the most therapy-resistant malignancies (Gogas et al, 2013). If left untreated, NMSCs also can become destructive, invading local tissues and causing disfigurement (Miller et al, 2010).

Statins, 3-hydroxy-3-methylglutaryl coenzyme A (HMG-CoA) reductase inhibitors have received increasing attention owing to their possible anticancer effects (Sarrabayrouse et al, 2007; Coimbra et al, 2010; Zhang et al, 2011).

According to a meta-analysis of 16 randomized control trials (RCTs) before 2009 (Bonovas et al, 2010), no association was found between statins and melanoma. Several observational studies also presented that statins have not identified anticancer effects (Marelli et al, 2011; Leung et al, 2013). However, other recent observational studies showed that statins may be associated with a lower risk of melanoma (Haukka et al, 2010; Jacobs et al, 2011). Thus, the effect of statins on the skin cancer risk remains to be determined.

\section{MATERIALS AND METHODS}

Selection criteria. The studies considered in this meta-analysis were RCTs, case-control or cohort studies that evaluated exposure to statins and risk of skin cancer (including melanoma and
NMSCs). The following inclusion criteria had to be fulfilled: (1) clearly defined and evaluated exposure to statins; (2) skin cancer incidence as the outcome of interest; (3) reported RR or odds ratio (OR) with $95 \%$ CI or provided data for their calculation. Studies reporting different measures of $\mathrm{RR}$ such as risk ratio, rate ratio, hazard ratio and OR were included because in practice they yield a similar RR estimate, given the absolute risk of skin cancer is low.

Identifying studies. Broad searches were conducted to identify all published literatures and meeting abstracts in Pubmed (-2013) and Web of Science (1985-2013) limited to those human subjects without limitation on language. Search terms included 3-hydroxy3-methylglutaryl coenzyme A (HMG-CoA reductase inhibitor), statin, atorvastatin, cerivastatin, fluvastatin, lovastatin, mevastatin, pravastatin, pitavastatin, rivastatin, rosuvastatin, simvastatin, combined with melanoma or non-melanoma or cancer or neoplasm or malignancy. Flow diagram is shown in Supplementary Figure 1. The detail of data collection is shown in Supplementary Material 1.

Quality assessment. The criteria adapted from the Cochrane handbook for systematic reviews of interventions (Higgins et al, 2011) and the validated Newcastle-Ottawa scale (NOS) (Wells et al, 2000) were used to assess the methodological quality of RCTs, case-control and cohort studies, respectively.

Statistical analysis. Study-specific risk estimates were extracted from each article, and log risk estimates were weighted by the

*Correspondence: Professor Q Chen; E-mail: qch.2009@163.com

Received 13 September 2013; revised 31 October 2013; accepted 12 November 2013; published online 24 December 2013

(c) 2014 Cancer Research UK. All rights reserved 0007-0920/14 
Table 1. Characteristics of included studies assessing the risk of skin cancer with statin use

\begin{tabular}{|c|c|c|c|c|c|c|c|}
\hline Author, year & Statin type & Study design & $\begin{array}{l}\text { Study } \\
\text { quality }\end{array}$ & Location & Time period & $\begin{array}{l}\text { Outcome } \\
\text { assessment }\end{array}$ & $\begin{array}{l}\text { Duration from statin } \\
\text { treatment start and } \\
\text { diagnosis }\end{array}$ \\
\hline Leung et al (2013) & $a, f, p r, r, s$ & Case-control & High & Taiwan & $\begin{array}{l}\text { Recruitment from } \\
01 \text { January } 2000 \\
\text { to } 31 \text { December } \\
2008\end{array}$ & $\begin{array}{l}\text { Investigated with } \\
\text { the corresponding } \\
\text { ICD-9-CM codes }\end{array}$ & $\begin{array}{l}\text { Statin continuously used for } \\
\text { at least } 6 \text { months before the } \\
\text { index date (date of } \\
\text { diagnosis and equivalent } \\
\text { date for controls). }\end{array}$ \\
\hline Koomen et al (2007) & $a, c, f, p r, r, s$ & Case-control & High & Netherland & $\begin{array}{l}\text { Recruitment from } \\
01 \text { January } 1991 \\
\text { to } 14 \text { December } \\
2004\end{array}$ & $\begin{array}{l}\text { The researchers } \\
\text { extracted and } \\
\text { recorded diagnosis } \\
\text { and date of primary } \\
\text { CM }\end{array}$ & $\begin{array}{l}\text { One or more statins for at } \\
\text { least } 6 \text { months of } \\
\text { cumulative prescription } \\
\text { duration in the } 3 \text { years } \\
\text { before } \mathrm{CM} \text {. }\end{array}$ \\
\hline Kaye and Jick (2004) & NR & Case-control & High & $\begin{array}{l}\text { The United } \\
\text { States }\end{array}$ & $\begin{array}{l}\text { Recruitment from } \\
1990 \text { to } 2002\end{array}$ & NR & $\begin{array}{l}\text { Received a prescription for } \\
\text { a statin within the year } \\
\text { before the index date, and } \\
\text { their first prescription was } \\
\text { recorded more than a year } \\
\text { before the index date. }\end{array}$ \\
\hline Haukka et al (2010) & $a, c, f, l, p r, r, s$ & Case-control & High & Finland & $\begin{array}{l}\text { Recruitment from } \\
01 \text { January } 1996 \\
\text { to } 31 \text { December } \\
2005\end{array}$ & $\begin{array}{l}\text { Obtained from } \\
\text { Finnish cancer } \\
\text { registry }\end{array}$ & $\begin{array}{l}\text { At least one prescription of } \\
\text { any prescription of any } \\
\text { statin between } 1 \text { January } \\
1996 \text { and } 31 \text { Dec } 2005 \text { and } \\
\text { had no cancer diagnosis at } \\
\text { the date of first purchase. }\end{array}$ \\
\hline Frohlich et al (2012) & $\mathrm{s}$ & Case-control & Moderate & Switzerland & $\begin{array}{l}\text { 1985-2007; } \\
\text { follow-up was } \\
\text { performed until } \\
\text { December } 2010\end{array}$ & $\begin{array}{l}\text { Defined as the } \\
\text { detection of any } \\
\text { malignant tumor }\end{array}$ & $\begin{array}{l}\text { Statin therapy was initiated, } \\
\text { usually 3-12 months after } \\
\text { transplantation in patients } \\
\text { who recieve transplants } \\
\text { after } 1995 \text { until the } \\
\text { occurrence of malignancy } \\
\text { or the end of the follow-up } \\
\text { period. }\end{array}$ \\
\hline Farwell et al (2008) & $a, f, I, p r, s$ & Cohort & Moderate & $\begin{array}{l}\text { The United } \\
\text { States }\end{array}$ & $\begin{array}{l}\text { Recruitment from } \\
01 \text { January } 1997 \\
\text { to } 31 \text { December } \\
2005\end{array}$ & $\begin{array}{l}\text { A physician blinded } \\
\text { to medication use } \\
\text { reviewed } 300 \\
\text { random charts with } \\
\text { a new ICD-9-CM } \\
\text { code for cancer } \\
\text { from patients who } \\
\text { were included in } \\
\text { our analyses. }\end{array}$ & $\begin{array}{l}\text { Beginning } 2 \text { years after his } \\
\text { or her entry date and } \\
\text { continuing until the first } \\
\text { occurrence of the first } \\
\text { appearance of cancer, } 1 \\
\text { year after the last date that } \\
\text { a prescription was filled for } \\
\text { a medication of interest, } \\
\text { death or the end of the } \\
\text { analysis period. }\end{array}$ \\
\hline $\begin{array}{l}\text { Curiel-Lewandrowski } \\
\text { et al (2011) }\end{array}$ & $a, f, l, p r, r, s$ & Case-control & High & $\begin{array}{l}\text { The United } \\
\text { States }\end{array}$ & $\begin{array}{l}\text { Recruitment from } \\
15 \text { March } 2004 \text { to } \\
18 \text { June 2007; } \\
\text { follow-up begin } \\
\text { from } 1997 \text { end in } \\
2007\end{array}$ & $\begin{array}{l}\text { Telephone } \\
\text { questionnaire }\end{array}$ & $\begin{array}{l}\text { Taking the drug at least } \\
\text { once weekly within a year } \\
\text { preceding the interview. }\end{array}$ \\
\hline Karp et al (2008) & $\begin{array}{l}a, f, l, s \\
\text { (exclude c, pr, r) }\end{array}$ & Cohort & Moderate & Canada & $\begin{array}{l}\text { Recruitment from } \\
01 \text { April } 1998 \text { to } \\
31 \text { March 2004; } \\
\text { follow-up through } \\
31 \text { March } 2005\end{array}$ & $\begin{array}{l}\text { Hospitalization with } \\
\text { cancer }\end{array}$ & $\begin{array}{l}\text { Followed from hospital } \\
\text { discharge until the } \\
\text { occurrence of the study } \\
\text { outcome, end of follow-up } \\
\text { (31 March 2005). }\end{array}$ \\
\hline Jacobs et al (2011) & $f, l, p r, s$ & Cohort & High & $\begin{array}{l}\text { The United } \\
\text { States }\end{array}$ & $\begin{array}{l}\text { Recruitment from } \\
1992 \text { to 1993; } \\
\text { follow-up begin } \\
\text { from } 1997 \text { end in } \\
2007\end{array}$ & $\begin{array}{l}\text { Self-administrated } \\
\text { questionnaire }\end{array}$ & $\begin{array}{l}\text { Questionnaire asked } \\
\text { participants to report } \\
\text { whether they had taken any } \\
\text { cholesterol-lowering drugs } \\
\text { regularly during the } \\
\text { past year. }\end{array}$ \\
\hline Marelli et al (2011) & NR & Cohort (retrospective) & High & $\begin{array}{l}\text { The United } \\
\text { States }\end{array}$ & $\begin{array}{l}\text { Recruitment from } \\
01 \text { January } 1990 \\
\text { to } 28 \text { February } \\
2009\end{array}$ & $\begin{array}{l}\text { Diagnosis of cancer } \\
\text { recorded in the } \\
\text { medical record } \\
\text { after time zero }\end{array}$ & $\begin{array}{l}\text { Time zero was defined as } \\
\text { the point at which patients } \\
\text { began to take statins or, if } \\
\text { never on statins, the date of } \\
\text { the first recorded low- } \\
\text { density lipoprotein or total } \\
\text { cholesterol level in the } \\
\text { database. }\end{array}$ \\
\hline
\end{tabular}




\section{Table 1. (Continued)}

\begin{tabular}{|c|c|c|c|c|c|c|c|}
\hline Author, year & Statin type & Study design & $\begin{array}{l}\text { Study } \\
\text { quality }\end{array}$ & Location & Time period & $\begin{array}{l}\text { Outcome } \\
\text { assessment }\end{array}$ & $\begin{array}{l}\text { Duration from statin } \\
\text { treatment start and } \\
\text { diagnosis }\end{array}$ \\
\hline $\begin{array}{l}\text { Vinogradova et al } \\
\text { (2011) }\end{array}$ & $a, c, f, p r, r, s$ & Nested case-control & High & $\begin{array}{l}\text { The United } \\
\text { Kingdom }\end{array}$ & $\begin{array}{l}01 \text { January 1998- } \\
01 \text { January } 2008\end{array}$ & NR & $\begin{array}{l}\text { At least } 2 \text { prescriptions in } \\
\text { the } 60 \text {-month period (or the } \\
98 \text {-month period for the } 10 \text { - } \\
\text { year analysis). }\end{array}$ \\
\hline Officers et al (2002) & pr & RCT follow-up & & $\begin{array}{l}\text { Australia } \\
\text { and New } \\
\text { Zealand }\end{array}$ & $\begin{array}{l}\text { Recruitment from } \\
\text { April } 1990 \text { to } \\
\text { December } 1992\end{array}$ & $\begin{array}{l}\text { All deaths and AM1 } \\
\text { are reviewed by } \\
\text { the outcome } \\
\text { assessment } \\
\text { committee }\end{array}$ & $\begin{array}{l}\text { Supplies of open label } \\
\text { pravastatin were provided } \\
\text { to patients for a mean of } 2 \\
\text { years beyond the end of the } \\
\text { RCT. }\end{array}$ \\
\hline Stegmayr et al (2005) & $a$ & RCT & & Sweden & $\begin{array}{l}\text { Enrolled from } \\
\text { February } 1998\end{array}$ & $\begin{array}{l}\text { Adverse event } \\
\text { reporting }\end{array}$ & $\begin{array}{l}\text { Safety analysis was } \\
\text { performed after } 6 \text { months } \\
\text { and again after } 2 \text { years. }\end{array}$ \\
\hline Shepherd et al (1995) & pr & RCT & & Scotland & $\begin{array}{l}\text { Recruitment } 01 \\
\text { February } 1989 \text { to } \\
30 \text { September } \\
1991\end{array}$ & $\begin{array}{l}\text { Based on subjects } \\
\text { recall, further } \\
\text { information was } \\
\text { obtained from } \\
\text { hospital records }\end{array}$ & 5 years. \\
\hline Sacks et al (1996) & pr & RCT & & $\begin{array}{l}\text { Canada } \\
\text { and the } \\
\text { United } \\
\text { States }\end{array}$ & $\begin{array}{l}\text { Recruitment from } \\
04 \text { December } \\
1989 \text { to } 31 \\
\text { December } 1991 \\
\text { ended between } \\
01 \text { January } 1996 \\
\text { and } 14 \text { February } \\
1996\end{array}$ & NR & $\begin{array}{l}\text { The median duration of } \\
\text { follow-up was } 5.0 \text { years. }\end{array}$ \\
\hline Jagtap et al (2012) & $a, c, f, I, p r, r, s$ & RCT & & $\begin{array}{l}\text { The United } \\
\text { States }\end{array}$ & $\begin{array}{l}\text { Recruitment } 01 \\
\text { October } 1993 \text { to } \\
31 \text { December } \\
\text { 1998; follow-up } \\
\text { through } 20 \\
\text { September } 2010\end{array}$ & $\begin{array}{l}\text { Centrally } \\
\text { adjudicated and } \\
\text { SEER-coded cases }\end{array}$ & $\begin{array}{l}\text { Cancer diagnoses were } \\
\text { updated in the } \\
\text { observational study or } \\
\text { semiannually in the RCT by } \\
\text { mail and/or telephone } \\
\text { questionnaires. }\end{array}$ \\
\hline $\begin{array}{l}\text { Heart Protection Study } \\
\text { Collaborative G (2005) }\end{array}$ & $\mathrm{s}$ & RCT & & $\begin{array}{l}\text { The United } \\
\text { Kingdom }\end{array}$ & $\begin{array}{l}\text { Recruitment from } \\
\text { July } 1994 \text { to May } \\
1997\end{array}$ & $\begin{array}{l}\text { Question } \\
\text { participants and } \\
\text { review the } \\
\text { calendar-packed } \\
\text { tablets remaining }\end{array}$ & $\begin{array}{l}\text { Mean duration of follow-up } \\
\text { was } 5.0 \text { years. }\end{array}$ \\
\hline GISSI (2000) & pr & RCT & & Italy & $\begin{array}{l}\text { Recruitment from } \\
\text { October } 1993 \text { to } \\
\text { September } 1995\end{array}$ & NR & 23 months \\
\hline Downs et al (1998) & I & RCT & & $\begin{array}{l}\text { The United } \\
\text { States }\end{array}$ & $\begin{array}{l}\text { Recruitment from } \\
30 \text { May } 1990 \text { to } 12 \\
\text { February } 1993\end{array}$ & NR & At least 5 years of follow-up. \\
\hline $\begin{array}{l}\text { Strandberg et al } \\
\text { (2004) }\end{array}$ & $\mathrm{s}$ & RCT follow-up & & $\begin{array}{l}\text { Denmark, } \\
\text { Finland, } \\
\text { Iceland, } \\
\text { Norway, } \\
\text { Sweden }\end{array}$ & $\begin{array}{l}\text { Recruitment from } \\
19 \text { May } 1988 \text { to } 16 \\
\text { August } 1989 \\
\text { follow-up end at } \\
01 \text { August } 1994\end{array}$ & $\begin{array}{l}\text { Classified by an } \\
\text { independent end } \\
\text { point committee } \\
\text { with hospital } \\
\text { records }\end{array}$ & $\begin{array}{l}\text { A 2-year, interim follow-up } \\
\text { study. }\end{array}$ \\
\hline Stein et al (2006) & $f$ & $\begin{array}{l}8 \text { RCTs (post hoc } \\
\text { analyses) }\end{array}$ & & Multicenter & NR & NR & NR \\
\hline
\end{tabular}

inverse of their variances to obtain a pooled risk estimate. Heterogeneity was assessed by using Cochrane Q statistic and estimating $I^{2}$ (Higgins et al, 2003). A fixed-effect model (MantelHaenszel) was used to calculate the pooled ORs when the test for heterogeneity was not statistically significant $(P>0.10)$, otherwise the random-effect model (DerSimonian and Laird) was employed (Song et al, 2001). Evidence of publication bias was determined using funnel plot and Egger's statistical test (Egger et al, 1997). Subgroup analyses were carried out by quality of study methodology, study design and duration of statin use. Sensitivity analyses were conducted to evaluate the robustness of meta-analysis results (Trikalinos et al, 2006). Cumulative meta-analysis was conducted to identify the change in trend of reporting risk over time.
Statistical analyses were performed using STATA 12.0 (STATA Corporation, College Station, TX, USA).

\section{RESULTS}

Characteristics of included studies. A total of 21 articles with 29 studies were identified, among which 24 studies focused on melanoma, whereas 14 studies reported NMSCs and 3 studies did not specify the classification of skin cancer (Table 1).

With respect to melanoma, 17 studies were post-hoc analyses or RCTs, 5 were case-control studies, and 2 were cohort studies. 
A total of 8433 cases of melanoma were cumulatively reported in 414627 patients, and 114708 individuals were classified as statin users. Concerning the NMSCs, 12 studies were post-hoc analyses or RCTs, 1 was case-control study and 1 was cohort study, of which 3354 cases and 99906 controls were eligible.

Quality assessment results. The qualities of studies were moderate to high (Table 1).

Melanoma. The association between statins and melanoma risk was not statistically significant assuming a random-effect model (RR, 0.94; 95\% CI, 0.85-1.04). However, moderate heterogeneity was observed $\left(P=0.07<0.1 ; I^{2}=33.8 \%\right)$. The funnel plot was symmetric and no publication bias was observed using Egger's test $(P=0.95)$.

Subgroup analysis (see Supplementary Table 1) represented that none of the stratifications (study design, location and study duration) could account for the heterogeneity observed in the overall analysis. Regarding long-term statin use in particular, the results did not materially change (RR, 0.93; 95\% CI, 0.73-1.18). Cumulative meta-analysis showed no significant change in trend of reporting risk from positive to negative.

NMSCs. The statin use with increased NMSCs was not statistically significant no matter assuming a fixed-effect model (RR, 1.12; 95\% CI, 1.05-1.20) or a random-effect model (RR, 1.03; 95\% CI, 0.901.19). The Cochran's Q-test had a $P$-value of 0.007 , and $I^{2}$ was $61.7 \%$, indicating there was moderate heterogeneity within the group. The $P$ values for the Egger's test were 0.16 , showing no evidence of publication bias.
Subgroup analysis showed that the results were not substantially changed by study design. In the sensitivity analysis, we identified the study by Stein et al (2006) and Haukka et al (2010) contributed most to the between-study variability.

RR estimates and 95\% CIs are listed in Tables 2 and 3.

\section{DISCUSSION}

There are debates regarding the association between statin use and skin cancer.

One view is that the immunomodulatory effects of statins may impair the host antitumor immune response by suppressing tumor-specific effector T-cell response, therefore leading to an increased cancer risk (Goldstein et al, 2009). Notably, immunosuppression represents an emerging risk factor for NMSCs. The immunomodulatory pleiotropic actions of statins resemble the immune phenotype, which predicts risk for post-transplantation NMSCs (Mausner-Fainberg et al, 2008; Carroll et al, 2010; Mascitelli and Goldstein, 2013). In addition, immunosuppressive actions of statin therapy may in part be related to increasing risk of a rare and aggressive neuroendocrine skin cancer, Merkel cell carcinoma (Kaae et al, 2010; Sahi et al, 2012).

On the contrary, in several in vitro and in vivo pre-clinical models of melanoma, statins have been presented to involve in anticancer activity (Sarrabayrouse et al, 2007; Coimbra et al, 2010; Ivanov and Hei, 2011). They may have anticancer effects through targeting on HMGCR and the mevalonate pathway, which have a

Table 2. Summary of adjusted RRs assessing the risk of melanoma with statin exposure

\begin{tabular}{|c|c|c|c|c|c|c|c|c|c|c|}
\hline \multirow[b]{2}{*}{ Author, year } & \multirow[b]{2}{*}{ Duration } & \multirow[b]{2}{*}{ RR } & \multirow[b]{2}{*}{ Low $\mathrm{Cl}$} & \multirow[b]{2}{*}{ High Cl } & \multicolumn{2}{|c|}{ All subjects } & \multicolumn{2}{|c|}{ On statins } & \multicolumn{2}{|c|}{ Not on statins } \\
\hline & & & & & Melanoma & Total & Melanoma & Total & Melanoma & Total \\
\hline Jagtap et al (2012) & Long & 1.14 & 0.91 & 1.43 & 1200 & 119726 & 89 & 8824 & 1111 & 110902 \\
\hline Marelli et al (2011) & Short & 1.08 & 0.85 & 1.37 & 259 & 10309 & 136 & 5215 & 123 & 5094 \\
\hline Jacobs et al (2011) & & & & & 1251 & 133255 & 411 & 28950 & 840 & 104305 \\
\hline Jacobs et al (2011) & Long & 0.79 & 0.66 & 0.96 & & & & & & \\
\hline Jacobs et al (2011) & Short & 0.89 & 0.75 & 1.06 & & & & & & \\
\hline Jacobs et al (2011) & Former & 0.64 & 0.46 & 0.89 & & & & & & \\
\hline Curiel-Lewandrowski et al (2011) & & 0.97 & 0.73 & 1.29 & 400 & 1000 & 109 & 276 & 291 & 724 \\
\hline Curiel-Lewandrowski et al (2011) & Short & 1.12 & 0.79 & 1.6 & & & & & & \\
\hline Curiel-Lewandrowski et al (2011) & Long & 0.84 & 0.48 & 1.48 & & & & & & \\
\hline Stein et al (2006) & Short & 0.40 & 0.10 & 1.55 & 10 & 6801 & 3 & 3512 & 7 & 3289 \\
\hline $\begin{array}{l}\text { Heart Protection Study } \\
\text { Collaborative G (2005) }\end{array}$ & Long & 1.66 & 0.78 & 3.54 & 27 & 20536 & 17 & 10269 & 10 & 10267 \\
\hline Stegmayr et al (2005) & Short & 0.35 & 0.01 & 8.39 & 1 & 143 & 0 & 70 & 1 & 73 \\
\hline GISSI (2000) & Short & 0.33 & 0.01 & 8.16 & 1 & 4271 & 0 & 2138 & 1 & 2133 \\
\hline Downs et al (1998) & Long & 0.52 & 0.27 & 0.99 & 41 & 6605 & 14 & 3304 & 27 & 3301 \\
\hline Sacks et al (1996) & Long & 1.33 & 0.30 & 5.94 & 7 & 4159 & 4 & 2081 & 3 & 2078 \\
\hline Shepherd et al (1995) & Long & 0.67 & 0.19 & 2.35 & 10 & 6595 & 4 & 3302 & 6 & 3293 \\
\hline Farwell et al (2008) & NR & 0.84 & 0.7 & 1.02 & 540 & 62842 & 304 & 37248 & 236 & 25594 \\
\hline Kaye and Jick (2004) & NR & 2.5 & 0.8 & 7.3 & 26 & 459 & 7 & 79 & 19 & 380 \\
\hline Koomen et al (2007) & Short & 0.98 & 0.78 & 1.2 & 1318 & 8104 & 96 & 599 & 1222 & 7505 \\
\hline Strandberg et al (2004) & Long & 1.29 & 0.48 & 3.45 & 16 & 4444 & 9 & 2221 & 7 & 2223 \\
\hline Officers et al (2002) & Short & 1.08 & 0.69 & 1.7 & 77 & 9014 & 39 & 4512 & 38 & 4502 \\
\hline Vinogradova et al (2011) & Short & 1.04 & 0.87 & 1.23 & 3249 & 16364 & 433 & 2108 & 2816 & 14256 \\
\hline
\end{tabular}


Table 3. Summary of adjusted RRs assessing the risk of skin cancer (except melanoma) with statin exposure

\begin{tabular}{|c|c|c|c|c|c|c|c|c|c|c|}
\hline \multirow[b]{2}{*}{ Author, year } & \multirow[b]{2}{*}{ Disease } & \multirow[b]{2}{*}{ RR } & \multirow[b]{2}{*}{ Low $\mathrm{Cl}$} & \multirow[b]{2}{*}{ High Cl } & \multicolumn{2}{|c|}{ All subjects } & \multicolumn{2}{|c|}{ On statins } & \multicolumn{2}{|c|}{ Not on statins } \\
\hline & & & & & Skin & Total & Skin & Total & Skin & Total \\
\hline Marelli et al (2011) & Non-melanoma & 0.98 & 0.81 & 1.19 & 394 & 10309 & 197 & 5215 & 197 & 5094 \\
\hline Haukka et al (2010) & Non-melanoma & 1.28 & 1.16 & 1.41 & 1735 & 50294 & 990 & 25445 & 745 & 24849 \\
\hline Strandberg et al (2004) & Non-melanoma & 1.04 & 0.62 & 1.74 & 57 & 4444 & 29 & 2221 & 28 & 2223 \\
\hline Frohlich et al (2012) & NR & 0.76 & 0.49 & 1.18 & 61 & 255 & 32 & 151 & 29 & 104 \\
\hline Karp et al (2008) & NR & 0.88 & 0.55 & 1.41 & 75 & 30076 & 26 & 11338 & 49 & 18738 \\
\hline Leung et al (2013) & NR & 1.62 & 0.662 & 3.875 & 88 & 34205 & 12 & 6841 & 76 & 27364 \\
\hline GISSI (2000) & Non-melanoma & 1.00 & 0.06 & 15.94 & 2 & 4271 & 1 & 2138 & 1 & 2133 \\
\hline Downs et al (1998) & Non-melanoma & 1.03 & 0.87 & 1.22 & 493 & 6605 & 250 & 3304 & 243 & 3301 \\
\hline Stein et al (2006) & Non-melanoma & 0.77 & 0.60 & 1.00 & 228 & 6801 & 103 & 3512 & 125 & 3289 \\
\hline Stegmayr et al (2005) & Non-melanoma & 1.20 & 1.00 & 1.45 & 445 & 20536 & 243 & 10269 & 202 & 10267 \\
\hline
\end{tabular}

role in the metabolic reprogramming of cancer (Clendening et al, 2010; Clendening and Penn, 2012).

This meta-analysis showed no evidence that statin use is associated with a substantially decreased or increased risk of skin cancer (neither melanoma nor NMSCs). The results were not significantly affected by study design, study location and long-term statin use, which reinforce our confidence in the validity of the conclusion. Our findings are in line with recent meta-analyses on the association between statin use and melanoma (Freeman et al, 2006; Bonovas et al, 2010). However, unlike in vitro and animal studies, meta-analyses do not demenstrate an effect of statins in humans, it is possible because of the inconsistent dosage and drug concentrations, some malignant cell lines are not inhibited by the same concentrations of statins achieved in humans (Freeman et al, 2006).

Moderate heterogeneity was identified in our meta-analysis, which should be considered with caution. There may be several factors contributing to the heterogeneity. The first reason is the multiple criteria for the diagnosis of skin cancer, which may introduce spectrum-of-disease bias. Second, detailed information for the type of statins was not provided, which made it hard to further investigate the potential difference between lipophilic and hydrophilic statins.

There could be several potential limitations in this metaanalysis. First, skin cancer (melanoma or NMSCs) was not the primary end point of the included RCTs; we were not able to obtain primary data regarding skin cancer diagnosis for all study participants. Second, even though the included studies had acceptable quality, detailed information of confounding factors was not provided (such as family history, skin color and sun exposure). To minimize the risk of misleading conclusions led by the lack of confounder control, we extracted adjusted RRs for different confounding factors whenever available. The third aspect deals with the varied definitions of drug exposure among eligible studies. Jacobs et al (2011) divided the participants into 'former user', 'current use' and 'no reported use' groups, whereas in other studies, participants were identified as statin users or non-statin users.

However, the present study has several strengths. First of all, 21 articles with 29 studies were included, reporting data of 11787 skin cancer cases. No exclusion criteria of language, location or study quality were applied. With large numbers of incident cases, metaanalysis could provide high statistical power. Moreover, no evidence of substantial publication bias was observed. Furthermore, the findings were similar in subgroup analysis of RCTs, case-control and cohort studies, although the methodological differences of original studies may introduce potential biases. In addition, even though moderate heterogeneity was observed, summary estimates were substantially unchanged after excluding the studies introducing most to the heterogeneity.

Two aspects should be noted in future studies. The potential use of statins for skin cancer prevention, especially melanoma, and the utility of testing statins as therapy in combination with chemotherapy are needed. In addition, because of the widespread use of statins, extending follow-up periods to identify potential effects on skin cancer in the longer-term statin use might be useful.

In conclusion, the meta-analysis indicates that there is no association between statin use and skin cancer risk on the basis of the findings of RCTs, case-control and cohort studies.

\section{CONFLICT OF INTEREST}

The authors declare no conflict of interest.

\section{REFERENCES}

Bonovas S, Nikolopoulos G, Filioussi K, Peponi E, Bagos P, Sitaras NM (2010) Can statin therapy reduce the risk of melanoma? A meta-analysis of randomized controlled trials. Eur J Epidemiol 25(1): 29-35.

Carroll RP, Segundo DS, Hollowood K, Marafioti T, Clark TG, Harden PN, Wood KJ (2010) Immune phenotype predicts risk for posttransplantation squamous cell carcinoma. J Am Soc Nephrol 21(4): 713-722.

Clendening JW, Pandyra A, Boutros PC, El Ghamrasni S, Khosravi F, Trentin GA, Martirosyan A, Hakem A, Hakem R, Jurisica I, Penn LZ (2010) Dysregulation of the mevalonate pathway promotes transformation. Proc Natl Acad Sci USA 107(34): 15051-15056.

Clendening JW, Penn LZ (2012) Targeting tumor cell metabolism with statins. Oncogene 31(48): 4967-4978.

Coimbra M, Banciu M, Fens MH, de Smet L, Cabaj M, Metselaar JM, Storm G, Schiffelers RM (2010) Liposomal pravastatin inhibits tumor growth by targeting cancer-related inflammation. J Control Release 148(3): 303-310.

Curiel-Lewandrowski C, Nijsten T, Gomez ML, Hollestein LM, Atkins MB, Stern RS (2011) Long-term use of nonsteroidal anti-inflammatory drugs decreases the risk of cutaneous melanoma: results of a United States case-control study. J Invest Dermatol 131(7): 1460-1468.

Downs JR, Clearfield M, Weis S, Whitney E, Shapiro DR, Beere PA, Langendorfer A, Stein EA, Kruyer W, Gotto Jr AM (1998) Primary prevention of acute coronary events with lovastatin in 
men and women with average cholesterol levels: results of AFCAPS/ TexCAPS. Air Force/Texas Coronary Atherosclerosis Prevention Study. JAMA 279(20): 1615-1622.

Egger M, Davey Smith G, Schneider M, Minder C (1997) Bias in meta-analysis detected by a simple, graphical test. BMJ 315(7109): 629-634.

Farwell WR, Scranton RE, Lawler EV, Lew RA, Brophy MT, Fiore LD, Gaziano JM (2008) The association between statins and cancer incidence in a veterans population. J Nat Cancer Inst 100(2): 134-139.

Freeman SR, Drake AL, Heilig LF, Graber M, McNealy K, Schilling LM, Dellavalle RP (2006) Statins, fibrates, and melanoma risk: a systematic review and meta-analysis. J Natl Cancer Inst 98(21): 1538-1546.

Frohlich GM, Rufibach K, Enseleit F, Wolfrum M, von Babo M, Frank M, Berli R, Hermann M, Holzmeister J, Wilhelm M, Falk V, Noll G, Luscher TF, Ruschitzka F (2012) Statins and the risk of cancer after heart transplantation. Circulation 126(4): 440-447.

GISSI (2000) Results of the low-dose (20 mg) pravastatin GISSI Prevenzione trial in 4271 patients with recent myocardial infarction: do stopped trials contribute to overall knowledge? GISSI Prevenzione Investigators (Gruppo Italiano per lo Studio della Sopravvivenza nell'Infarto Miocardico). Ital Heart J 1(12): 810-820.

Gogas H, Polyzos A, Kirkwood J (2013) Immunotherapy for advanced melanoma: fulfilling the promise. Cancer Treat Rev 39: 879-885.

Goldstein MR, Mascitelli L, Pezzetta F (2009) The double-edged sword of statin immunomodulation. Int J Cardiol 135(1): 128-130.

Haukka J, Sankila R, Klaukka T, Lonnqvist J, Niskanen L, Tanskanen A, Wahlbeck K, Tiihonen J (2010) Incidence of cancer and statin usage-record linkage study. Int J Cancer 126(1): 279-284.

Heart Protection Study Collaborative G (2005) The effects of cholesterol lowering with simvastatin on cause-specific mortality and on cancer incidence in 20,536 high-risk people: a randomised placebo-controlled trial [ISRCTN48489393]. BMC Med 3: 6.

Higgins JP, Altman DG, Gotzsche PC, Juni P, Moher D, Oxman AD, Savovic J, Schulz KF, Weeks L, Sterne JA (2011) The Cochrane Collaboration's tool for assessing risk of bias in randomised trials. BMJ 343: d5928.

Higgins JP, Thompson SG, Deeks JJ, Altman DG (2003) Measuring inconsistency in meta-analyses. BMJ 327(7414): 557-560.

Ivanov VN, Hei TK (2011) Regulation of apoptosis in human melanoma and neuroblastoma cells by statins, sodium arsenite and TRAIL: a role of combined treatment versus monotherapy. Apoptosis 16(12): $1268-1284$.

Jacobs EJ, Newton CC, Thun MJ, Gapstur SM (2011) Long-term use of cholesterol-lowering drugs and cancer incidence in a large United States cohort. Cancer Res 71(5): 1763-1771.

Jagtap D, Rosenberg CA, Martin LW, Pettinger M, Khandekar J, Lane D, Ockene I, Simon MS (2012) Prospective analysis of association between use of statins and melanoma risk in the Women's Health Initiative. Cancer 118(20): 5124-5131.

Kaae J, Hansen AV, Biggar RJ, Boyd HA, Moore PS, Wohlfahrt J, Melbye M (2010) Merkel cell carcinoma: incidence, mortality, and risk of other cancers. J Natl Cancer Inst 102(11): 793-801.

Karp I, Behlouli H, Lelorier J, Pilote L (2008) Statins and cancer risk. Am J Med 121(4): 302-309.

Kaye JA, Jick H (2004) Statin use and cancer risk in the General Practice Research Database. Br J Cancer 90(3): 635-637.

Koomen ER, Joosse A, Herings RM, Casparie MK, Bergman W, Nijsten T, Guchelaar HJ (2007) Is statin use associated with a reduced incidence, a reduced Breslow thickness or delayed metastasis of melanoma of the skin? Eur J Cancer 43(17): 2580-2589.

Leung HW, Chan AL, Lo D, Leung JH, Chen H-L (2013) Common cancer risk and statins: a population-based case-control study in a Chinese population. Expert Opi Drug Saf 12(1): 19-27.

Marelli C, Gunnarsson C, Ross S, Haas S, Stroup DF, Cload P, Clopton P, DeMaria AN (2011) Statins and risk of cancer: a retrospective cohort analysis of 45,857 matched pairs from an electronic medical records database of 11 million adult Americans. J Am Coll Cardiol 58(5): 530-537.

Mascitelli L, Goldstein MR (2013) Statins in dermatology: is nonmelanoma skin cancer the dark side of the moon? Int J Dermatol 52(7): 899-900.
Mausner-Fainberg K, Luboshits G, Mor A, Maysel-Auslender S, Rubinstein A, Keren G, George J (2008) The effect of HMG-CoA reductase inhibitors on naturally occurring CD4 $+\mathrm{CD} 25+\mathrm{T}$ cells. Atherosclerosis 197(2): 829-839.

Miller SJ, Alam M, Andersen J, Berg D, Bichakjian CK, Bowen G, Cheney RT, Glass LF, Grekin RC, Kessinger A, Lee NY, Liegeois N, Lydiatt DD, Michalski J, Morrison WH, Nehal KS, Nelson KC, Nghiem P, Olencki T, Perlis CS et al. (2010) Basal cell and squamous cell skin cancers. J Natl Compr Cancer Netw 8(8): 836-864.

Officers A, Antihypertensive CftACRGT, Trial L-LTtPHA (2002) Major outcomes in moderately hypercholesterolemic, hypertensive patients randomized to pravastatin vs usual care: The Antihypertensive and Lipid-Lowering Treatment to Prevent Heart Attack Trial (ALLHAT-LLT). JAMA 288(23): 2998-3007.

Sacks FM, Pfeffer MA, Moye LA, Rouleau JL, Rutherford JD, Cole TG, Brown L, Warnica JW, Arnold JM, Wun CC, Davis BR, Braunwald E (1996) The effect of pravastatin on coronary events after myocardial infarction in patients with average cholesterol levels. Cholesterol and Recurrent Events Trial investigators. N Eng J Med 335(14): 1001-1009.

Sahi H, Koljonen V, Bohling T, Neuvonen PJ, Vainio H, Lamminpaa A, Kyyronen P, Pukkala E (2012) Increased incidence of Merkel cell carcinoma among younger statin users. Cancer Epidemiol 36(5): 421-424.

Sarrabayrouse G, Synaeve C, Leveque K, Favre G, Tilkin-Mariame AF (2007) Statins stimulate in vitro membrane FasL expression and lymphocyte apoptosis through RhoA/ROCK pathway in murine melanoma cells. Neoplasia 9(12): 1078-1090.

Shepherd J, Cobbe SM, Ford I, Isles CG, Lorimer AR, MacFarlane PW, McKillop JH, Packard CJ (1995) Prevention of coronary heart disease with pravastatin in men with hypercholesterolemia. West of Scotland Coronary Prevention Study Group. N Eng J Med 333(20): 1301-1307.

Society AC (2013) Cancer Facts \& Figures 2013.

Song F, Sheldon TA, Sutton AJ, Abrams KR, Jones DR (2001) Methods for exploring heterogeneity in meta-analysis. Eval Health Prof 24(2): 126-151.

Stegmayr BG, Brannstrom M, Bucht S, Crougneau V, Dimeny E, Ekspong A, Eriksson M, Granroth B, Grontoft KC, Hadimeri H, Holmberg B, Ingman B, Isaksson B, Johansson G, Lindberger K, Lundberg L, Mikaelsson L, Olausson E, Persson B, Stenlund H, Wikdahl AM (2005) Low-dose atorvastatin in severe chronic kidney disease patients: a randomized, controlled endpoint study. Scand J Urol Nephrol 39(6): 489-497.

Stein EA, Corsini A, Gimpelewicz CR, Bortolini M, Gil M (2006) Fluvastatin treatment is not associated with an increased incidence of cancer. Int J Clin Pract 60(9): 1028-1034.

Strandberg TE, Pyorala K, Cook TJ, Wilhelmsen L, Faergeman O, Thorgeirsson G, Pedersen TR, Kjekshus J (2004) Mortality and incidence of cancer during 10-year follow-up of the Scandinavian Simvastatin Survival Study (4S). Lancet 364(9436): 771-777.

Trikalinos TA, Salanti G, Khoury MJ, Ioannidis JP (2006) Impact of violations and deviations in Hardy-Weinberg equilibrium on postulated gene-disease associations. Am J Epidemiol 163(4): 300-309.

Vinogradova Y, Coupland C, Hippisley-Cox J (2011) Exposure to statins and risk of common cancers: a series of nested case-control studies. BMC cancer 11: 409.

Wells GA, Shea B, O'Connell D, Peterson J, Welch V, Losos M, Tugwell P (2000) The Newcastle-Ottawa Scale (NOS) for assessing the quality if nonrandomized studies in meta-analyses. Available at http://www. medicine.mcgill.ca/rtamblyn/Readings $\% 5$ CThe $\% 20$ Newcastle $\% 20$ $\% 20$ Scale $\% 20$ for $\% 20$ assessing $\% 20$ the $\% 20$ quality $\% 20$ of $\% 20$ nonrandomised\%20studies\%20in\%20meta-analyses.pdf.

Zhang S, Doudican NA, Quay E, Orlow SJ (2011) Fluvastatin enhances sorafenib cytotoxicity in melanoma cells via modulation of AKT and JNK signaling pathways. Anticancer Res 31(10): 3259-3265.

This work is published under the standard license to publish agreement. After 12 months the work will become freely available and the license terms will switch to a Creative Commons AttributionNonCommercial-Share Alike 3.0 Unported License.

Supplementary Information accompanies this paper on British Journal of Cancer website (http://www.nature.com/bjc) 